\title{
Use of serological diagnostic techniques in the control and eradication of caprine arthritis encephalitis: an update
}

\author{
Uso de técnicas sorológicas de diagnóstico no controle e erradicação da artrite encefalite \\ caprina: atualização
}

\author{
Jamili Maria Suhet MUSSI ${ }^{1,6}$; Aurora Maria Guimarães GOUVEIA ${ }^{1,6}$; Adriana CORTEZ ${ }^{2}$; \\ Andrey Pereira LAGE ${ }^{1,6}$; Alessandro de Sá GUIMARÃES ${ }^{3,4,6}$; Marcos Bryan HEINEMANN ${ }^{5,6}$ \\ ${ }^{1}$ Universidade Federal de Minas Gerais, Escola de Veterinária, \\ Departamento de Medicina Veterinária Preventiva, Belo Horizonte -MG, Brazil \\ ${ }^{2}$ Universidade de Santo Amaro, Curso de Medicina Veterinária, São Paulo - SP, Brazil \\ ${ }^{3}$ Embrapa Gado de Leite, Núcleo de Saúde Animal e Microbiologia do Leite, Juiz de Fora - MG, Brazil \\ ${ }^{4}$ Universidade Federal de Lavras, Departamento de Medicina Veterinária, Lavras - MG, Brazil \\ ${ }^{5}$ Universidade de São Paulo, Faculdade de Medicina Veterinária e Zootecnia, \\ Departamento de Medicina Veterinária Preventiva e Saúde Animal, São Paulo - SP, Brazil \\ ${ }^{6}$ Grupo de Extensão da Pesquisa em Ovinos e Caprinos (GEPOC), Belo Horizonte - MG, Brazil
}

\begin{abstract}
Caprine arthritis encephalitis (CAE) is a chronic disease caused by a small ruminant lentivirus (SRLV), which causes significant losses in goat breeding. The actual state of animal infection with SRLV is difficult to determine due to a complex pathogenesis of the virus, including factors such as delayed or intermittent seroconversion in serological tests. Several serological techniques are available for disease diagnosis, such as screening or confirmation tests, which are different in sensitivity and specificity. Regarding the choice of the test to be applied, availability of commercial immunoreagents, team training, antigen used, and cost of techniques must be considered. This review presents the serological methods available for use in different stages of CAE control and eradication programs, and management measures to be adopted in conjunction with serological diagnosis of the disease.
\end{abstract}

Keywords: Caprine arthritis encephalitis virus. CAEV. Small ruminant lentivirus. SRLV. Diagnosis. Control.

\section{Resumo}

A artrite encefalite caprina (CAE) é uma enfermidade crônica causada por um lentivírus de pequenos ruminantes (LVPR), que ocasiona perdas significativas na caprinocultura. O estado real da infecção animal pelo LVPR é de difícil determinação em virtude da complexa patogenia do vírus, incluindo fatores como soroconversão tardia ou intermitente em testes sorológicos. Para o diagnóstico da enfermidade, diversas técnicas sorológicas estão disponíveis, como testes de triagem ou confirmatórios, com variações na sensibilidade e especificidade. Para escolha do teste a ser usado, a disponibilidade de imunorreagentes comerciais, o treinamento da equipe, o antígeno utilizado, e o custo das técnicas devem ser considerados. Esta revisão apresenta os métodos sorológicos disponíveis para uso em diferentes fases dos programas de controle e erradicação da CAE e as medidas de manejo que devem ser adotadas em conjunto com o diagnóstico sorológico da enfermidade.

Palavras-chave: Vírus da artrite encefalite caprina. CAEV. Lentivírus de pequenos ruminantes. LVPR. Diagnóstico. Controle.

\section{Introduction}

Caprine arthritis encephalitis (CAE) is a common disease in many countries. It has caused significant losses due to sacrifice of infected animals, loss of genetic material, death of young animals, decrease in milk production, failure in mounting or even in semen collection from breeders with severe joint disorders, and restriction on trade and transit of animals from

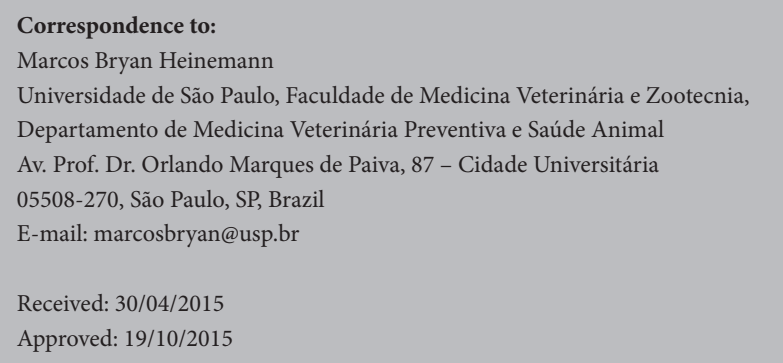


infected areas to disease-free areas (PETERHANS et al., 2004; MARTÍNEZ-NAVALÓN et al., 2013).

This disease may also jeopardize profitability of goat breeding due to less weight gain, animal weakness, and predisposition to the occurrence of secondary infection and gastrointestinal parasitism (CARNEIRO et al., 2011). In addition to economic losses, the disease impacts animal welfare as it reduces the quality of life of clinically affected animals due to pain and difficulty in walking (PETERHANS et al., 2004).

The etiologic agent of CAE belongs to the family Retroviridae, subfamily Orthoretrovirinae, genus Lentivirus (ICTV, 2013). The CAE virus (CAEV) and Maedi-Visna virus (MVV) compose the group of small ruminant lentiviruses, which are antigenically related but genetically distinct (PISONI; QUASSO; MORONI, 2005; PISONI et al., 2007; ICTV, 2013). Sheep and goats reared together can be infected with both CAEV and MVV circulating in the herd. This knowledge changed the approach of the epidemiological aspects of the disease as well as its control and eradication. As a result, the etiologic agent of CAE has been referred to as small ruminant lentivirus (SRLV) (BERTONI, 2007; PISONI; QUASSO; MORONI, 2005; PISONI et al., 2007; GJERSET et al., 2009).

Goat SRLV is a linear and positive-sense RNA virus whose genome has two identical RNA molecules responsible for encoding three structural genes: gag, env and pol (SCHOBORG, 2002; RAVAZZOLO; COSTA, 2007; BRANDÃO et al., 2013). The gag gene is first expressed as a gag polyprotein (p55), which is cleaved at the cell surface yielding proteins of the viral capsid (p28), matrix (p19), and nucleocapsid (p16) (BRANDÃO et al., 2013). The env gene encodes the phospholipid envelope comprising the surface glycoprotein gp135 and transmembrane protein gp45, which interact with the target cell receptor and act on cell penetration (RAVAZZOLO; COSTA, 2007). The pol gene encodes part of a polyprotein (gag-pol-pro) whose cleavage products always include the reverse transcriptase, integrase, and protease (PETROPOULOS, 1997).

On the basis of sequencing and phylogenetic analysis of the gag and pol genes, SRLV are divided into five phylogenetic groups (A, B, C, D and E). Group A comprises the prototypes of sheep SRLV isolates and is divided into 15 different subtypes (A115). Group B includes the prototypes of goat SRLV isolates and is divided into three different subtypes (A1-3). Group C comprises SRLV isolates of goats from Norway, whereas Group D comprises isolates of goats from Switzerland and Spain. Group E is divided into two subtypes of isolates of goats from northern Italy (E1) and the island of Sardinia (E2). Among the subtypes, genotype B1 is considered the prototype of the CAEV and genotype A1 of the MVV (SHAH et al., 2004; CARDINAUX et al., 2013; SANTRY et al., 2013). Heterogeneity of viral samples is directly related to errors in viral RNA transcription by reverse transcriptase (CALLADO; CASTRO; TEIXEIRA, 2001).

Infections caused by SRLV persist due to three characteristics that enable viruses to escape from the host immune system. They are as follows: integration of proviral DNA into the cellular genome, replication in cells of the immune system, and high rate of mutation due to failure in the transcription of its RNA (CALLADO; CASTRO; TEIXEIRA, 2001).

Caprine arthritis encephalitis is a chronic and infectious disease with a long period of incubation and a slow and progressive clinical course (NOGUEIRA; PINHEIRO; ALVES, 2009). It presents clinically in the nervous, arthritic, mammary, and pulmonary forms. However, only 25-30\% of infected animals develop clinical signs of the disease (PETERHANS et al., 2004). In young animals, the disease can cause leukoencephalomyelitis. In adult animals, the most common clinical sign is an increase in the carpometacarpal joint, which is present in $12-40 \%$ of the infected animals (ALVES, 1999).

Infection with SRLV can lead to mastitis with 
changes in the consistency of the mammary gland and presence of nodules, and a diffuse hardening in the mammary parenchyma can also occur. This clinical form is diagnosed in the range of $6.8-19.7 \%$ of infected animals and can cause changes in physicochemical characteristics of milk, with resulting economic losses for farmers and dairy industry (BIRGEL JUNIOR et al., 2007).

Animals that are asymptomatic carriers and/or false negative in serological tests are critical in controlling the disease, since they remain as virus transmitters in the herd. This scenario may be favored by genetics and age of animals, management, nutrition, concurrent infection, pathogenicity of viral strain, circulating antibody levels (ALVES, 1999), diagnostic technique, and antigens used for diagnosis.

Caprine arthritis encephalitis is more prevalent in technified properties, aimed at milk production, with intensive breeding, since in this system the animal management practices, such as confinement and use of collective feeding bottles, facilitate disease transmission (PINHEIRO et al., 2004). Prevalence of CAE is also higher in animals older than two years and pure breeds (PINHEIRO; GOUVEIA; ALVES, 2001).

Some management practices, such as lamb feeding with goat's milk, use of common equipment for sheep and goats, and contact among animals are important factors that affect dissemination of cross-species infection (GJERSET et al., 2009). Purchase of animals and their introduction into the herd without proper health care is a risk factor for infection with SRLV. Numerous herds of 50 or more animals can also be a risk factor for presence of the disease (LIN et al., 2011).

Given the complex pathogenesis of SRLV, the diagnosis should not be based on clinical symptoms since the disease is chronic, symptoms nonspecific, and the state of asymptomatic carrier is frequent. Thus, laboratory tests are indicated to determine the actual state of animal infection.

\section{Seroconversion}

The animals produce anti-SRLV antibodies after infection. However, seroconversion may occur weeks to months post infection (pi) and are often detected in the third week pi onwards (CHEEVERS; MCGUIRE, 1988). Generally, a peak in antibody levels is observed. Then they decline to a lower although stable level (ANDRÉS et al., 2005). In some cases, however, an intermittency in antibody levels can be noted and it may cause false-negative results in serologic tests. Intermittency has been observed in a variety of antigens such as p14, p16, and p28 (capsid proteins) and also in gp135 (envelope protein), regardless of the assay used (gel immunodiffusion, ELISA, or Western blotting) (RIMSTAD et al., 1993; HANSON; HYDBRING; OLSSON, 1996; CRUZ, 2009; CRUZ et al., 2009a).

Cruz (2009) observed intermittency in antibody titers in goats inoculated with either the Cork sample of CAEV or the wild virus. Such fluctuation was observed in a naturally-infected goat. A trial was carried out with goats inoculated with blood from a naturally-infected animal $(\mathrm{n}=4)$ and the Cork sample of CAEV $(n=5)$. In the group inoculated with infected blood, seroconversion started 49 days $p i$, varying in the range of 45-165 (minimummaximum) days. In the group inoculated with the Cork sample, seroconversion started 56 days $p i$, and one of the animals showed seroconversion 265 days $p i$, indicating that the serological profile fluctuates according to the virus variant. According to Adams et al. (1980), antibodies to CAEV were detected in the period of 21-35 days' $p i$, with a peak in the period of 49-77 days. The antibody titers declined temporarily stabilizing 271 days $p i$, and the seroconversion time in experimental infections varied in the range of 3-12 weeks (mean value: 6 weeks).

Some animals may present intermittent responses in serological tests and the reasons for such fluctuations between positivity and negativity are not well understood. However, they may be related to 
the analytical sensitivity of the diagnostic test used (KLEIN et al., 1985; ROWE; EAST, 1997; ANDRÉS et al., 2005), host genetic factors, differences between sheep and goats in the stimulus of the humoral response to either some antigens or the same viral strain (FLURI et al., 2006; RACHID et al., 2013), and SRLV genotype, which influences the rates of viral replication, in which the animals infected with more virulent samples have earlier and higher titers (KAJIKAWA; LAIRMORE; DEMARTINI, 1990; RIMSTAD et al., 1993).

Given that some animals may present low antibody titers, delayed seroconversion, or intermittent seropositive reactions, the serological diagnosis of animals infected with SRLV has been discussed (TIGRE; CAMPOS; SARDI, 2006). Due to the existing heterogeneity in viral strains, care should be taken when selecting the antigen to be used in the diagnostic test. The use of antigens containing immunodominant specific epitopes favors identification of different phylogenetic groups. However, they interfere with sensitivity and specificity according to the type of circulating viral sample in the study population (PETERHANS et al., 2004; CARDINAUX et al., 2013). Reina et al. (2009) suggest that use of antigens prepared from whole virus particle could compensate for the heterogeneity of viral strains due to the variability in these epitopes. In order to diagnose samples related to the CAEV prototype, sensitivity of antigens produced from goat SRLV is higher than that of SRLV sheep, which is more effective for investigating samples related to the prototype MVV (KNOWLES JUNIOR et al., 1994; ABREU et al., 1998).

\section{Diagnostic tests}

Early diagnosis in both monitoring of control and prevention of SRLV infection is crucial, and must be done essentially by detection of antibody or virus in the animals (REINA et al., 2009).

Various laboratory methods for diagnosis of SRLV are available. Each method has advantages and disadvantages, and both diagnostic and analytical sensitivity and specificity of tests must be evaluated before they are used for control and eradication in health programs.

These methods can be categorized as screening (immunodiffusion in agarose gel, IDAG; and enzyme immunoassay, ELISA), supplementary serum (Western blot, WB) or molecular assays such as polymerase chain reaction (PCR) for the detection of CAEV (proviral DNA) directly in the genetic material or associated with a step of reverse transcription from viral RNA (ANDRÉS et al., 2005). PCR is sensitive to changes within the target nucleotide sequences. Recent studies show that a significant variation exists among isolates of SRLV from different geographical places (MODOLO et al., 2009), and the primers and probes should be in highly-conserved regions of the viral genome.

As SRLV infection is persistent, antibody detection is a valuable tool to identify infected animals. Most serological assays for indirect diagnosis of CAE are performed using AGID and/or ELISA. Other serological techniques such as WB and dot blot (DB) have more limited use due to cost, speed, convenience, or availability. The World Organization for Animal Health (OIE) recommends the use of AGID or ELISA for diagnosis of SRLV infection (VAREA et al., 2001; OIE, 2008; REINA et al., 2009).

In addition to the sensitivity and specificity of the assay, its cost and consequent impact on implementation of a control or eradication program should also be considered. Pinheiro et al. (2006a) conducted a study on cost of CAE serological tests. These authors considered the unit cost of laboratory tests for MIDGA and observed a significant impact on a control program: AGID on slide instead of Petri dish (US\$ 0.71), indirect ELISA (US\$ 1.22), and DB (US\$ 1.00). According to these authors, DB test has diagnostic sensitivity similar to (and costs $22 \%$ less expensive than) those of ELISA; however, it is faster and more sensitive (although 29\% more expensive) than MIDGA. 


\section{Agarose gel immunodiffusion (AGID)}

Agarose gel immunodiffusion is one of the techniques recommended by the OIE for international trade in animals (OIE, 2008). In AGID, an identity line (precipitation line), which is due to multiple interactions between antibodies present in test serum and epitopes of viral proteins derived from cell culture, can be seen (HERRMANN-HOESING, 2010). This antigen-antibody identity line can be seen within $24 \mathrm{~h}$ but the final reading should be taken in 48-72 $\mathrm{h}$ as the results become stable during this time interval (ABREU et al., 1998).

Due to availability of commercial immunoreactants and a greater ease in both immediate implementation and staff training, AGID is among the most used techniques in the diagnosis of SRLV. It can be used in animal screening, serological monitoring within a control program in the herd, and epidemiological survey (PINHEIRO et al., 2010). In addition, AGID allows processing a large number of samples and quickly detecting infected animals (TIGRE; CAMPOS; SARDI, 2006). The diagnostic specificity and sensitivity of the test are considered suitable for initial use in control programs (Table 1).

False-negative results may occur due to a delayed seroconversion in some animals, slower antibody production, or existence of animals at an early stage of infection that have not yet produced antibodies at levels detectable by AGID (ROWE et al., 1991).

In goats, false-positive results can occur by passive transfer of antibodies via colostrum. This antibody titer is reduced after 2-3 months of age. For this reason, serological test should only be recommended after this period (ROWE et al., 1992a). However, virus transmission also by the colostrum, whereby passive antibodies are transmitted to goats, is a relevant possibility to consider (GOUVEIA, 2012). Another disadvantage of AGID is that it is unsuitable for use in different types of samples, e.g., milk (REINA et al., 2009).

Rodrigues et al. (2014) evaluated three serological tests for CAEV: AGID, ELISA-i, and WB that could be used in a Brazilian national control program. In the screening of a herd, adult goats showed anti-CAEV antibodies in AGID (6.8\%), ELISA-i (14.9\%), and WB (39.2\%). Among neonate goats, none was positive by AGID, whereas $1.4 \%$ were seropositive by WB. These results show that $\mathrm{WB}$ has detected a higher number of positive animals and AGID is not indicated to detect anti-CAEV antibodies in newborn goats.

Analytical sensitivity of AGID depends on both virus strain and antigen used in the assay. E.g., in AGID, the number of infected goats detected with the use of antigen gp135 is higher than that with antigen p28, although some sera only react to p28. Use of both proteins is recommended to increase the assay sensitivity (ADAMS; GORHAM, 1986).

The homologous antigen (CAEV) provides a greater sensitivity in relation to the heterologous antigen (MVV) (ALVES, 1999). The two antigens reacted with goat serum in AGID and both showed 100\% specificity, and the homologous antigen (CAEV: 91\%; MVV: $56 \%$ ) showed a $35 \%$ increase in sensitivity (KNOWLES JUNIOR et al., 1994; ABREU et al.,

Table 1 - Sensitivity and specificity of serological tests for diagnosis of SRLV - Belo Horizonte - 2015

\begin{tabular}{lccl}
\hline Tests & Sensitivities (\%) & Specificities $(\%)$ & References \\
\hline AGID & $45.8-91.0$ & $93.3-100$ & KNOWLES JR et al., 1994; VAREA et al., 2001; CRUZ et al., 2009b \\
ELISA & $93.9-100$ & $70.8-100$ & SALMAN et al., 1999; SIMARD et al., 2001; CORTEZ-MOREIRA; \\
& & OELEMANN; LILENBAUM, 2005; LARA et al., 2002; CRUZ et al., 2009b; \\
& & TORRES et al., 2009 \\
WB & $84.6-100$ & $72.5-76.5$ & RODRIGUES et al., 2014
\end{tabular}

Abbreviations: ELISA - enzyme-linked immunosorbent assay; AGID - agar-gel immunodiffusion test; and WB - Western blot assay 
1998; PETERHANS et al., 2004). The homologous antigen has a higher detection capability in sera with low antibody titers (ABREU et al., 1998) although a great genetic similarity between the two viruses exists (CRUZ et al., 2013).

When use of tests with greater sensitivity is impossible, AGID is used as the only technique available to monitor the measures proposed in CAE control programs. In this case, alternating the use of diagnostic kits with different viral proteins is recommended. Extended use of a single type of antigen to detect a specific protein causes loss of its ability to detect seropositive animals because those carrying the virus that expresses the protein detected by the test were already withdrawn from the herd (PINHEIRO et al., 2010; GOUVEIA, 2012).

Despite recommendations for use of diagnostic kits with different viral proteins (or antigens produced with the use of more than one viral protein) as described above, they may be unfeasible in the routine due to the burden of cost and hindering adoption of CAE control programs. In Brazil, only one commercial antigen kit (Biovetech ${ }^{\circledR}$, Recife, PE) containing solely the CAEV p28 antigen for diagnosis by AGID is available. In other countries, other commercial kits are available, not only with the p28 antigen (Capriclear 300 Kit, Veterinary Laboratory Agency, UK, and kit from Institut Pourquier, France), but also with the CAEV viral protein gp135 (caprine arthritis-encephalitis/ovine Progressive pneumonia antibody test kit, Veterinary Diagnostic Technology, Inc. ${ }^{\circledR}$, Wheat Ridge, CO, USA).

\section{Immunoenzymatic assays (ELISA)}

ELISA is also a test recommended by the OIE for international trade in animals. Currently, ELISA is the test most widely used in the CAE control programs in most of the world (OIE, 2008) but is not available as a routine in Brazil.

The high sensitivity of ELISA (Table 1) and its great capability to detect low antibody titers are well known. This assay is inexpensive, can be used for both rapid determinations of anti-SRLV antibodies in sheep and goats and screening of a large number of samples. It is an excellent assay for use in screening herds as it has a high diagnostic sensitivity. Due to its lower diagnostic specificity, it is indicated for use in conjunction with a high-specificity assay such as the AGID test (PINHEIRO et al., 2010; GOUVEIA, 2012; RODRIGUES et al., 2014).

ELISA allows earlier detection of seroconversion in animals, being more sensitive than AGID. ELISA-i was produced with cell culture antigen of goat synovial membrane infected with CAEV and treated with sodium dodecyl sulfate (SDS), being more sensitive and able to detect positive animals almost a year before AGID (TORRES et al., 2009).

Lara et al. (2003) showed that ELISA detects seropositive animals earlier than AGID. In experimental infection of goats with contaminated milk and serum, seroconversion was detected 45 days $p i$ in most animals by ELISA (80\%), but not by AGID (20\%). In a group of goats infected with contaminated colostrum, seroconversion was detected in $60 \%$ of the animals at 45 days by ELISA and 60 days pi by AGID. Cruz et al. (2009b) used ELISAi and AGID produced with the same antigen to identify antibodies in goats with and without clinical signs of CAE, and ELISAi showed better performance in the detection of seropositive animals, detecting low antibody titers, and indicating use of ELISA as a test to screen the herd in control programs.

Not requiring production of monoclonal antibody is one advantage of ELISAi, but serum generally requires a dilution from 1:10 to $1: 100$ to minimize the background signal. With such a dilution, usually there is an increase in the number of false-negative results, because it can present as negative in the test when a weakly-positive serum is diluted (HERRMANNHOESING, 2010). Another advantage of ELISAi is that antigens of whole viruses can be used, thus increasing the sensitivity of the test in relation to 
ELISA, which is produced with a single protein or a mixture of recombinant proteins (SIMARD et al., 2001).

Serological analysis by ELISA usually requires the use of serum. As an alternative, milk or milk whey samples can be used without disagreement between results. Use of these samples is advantageous since collection of material is non-invasive and can be done directly from expansion tanks. Thus, population serological surveys can be conducted with minimum cost and easier monitoring of SRLV in lactating goats. Low antibody concentration in milk and presence of fat, which can affect reading and thus cause falsepositive results, are the disadvantages of using this type of sample. In these cases, use of milk whey is effective in eliminating the presence of high fat concentration (PLAZA et al., 2009).

Barquero et al. (2011) compared performance of ELISA in detecting anti-SRLV antibodies in blood and milk samples and they found 90\% agreement in their results. These facts confirmed that milk could be used in the serological diagnosis of CAE with the advantages of reducing exam cost and facilitating sample collection.

Seminal fluid is an alternative to clinical specimen in detecting antibodies to SRLV in asymptomatic animals. With this type of sample, the values for sensitivity and specificity of ELISA are close to those found in serum. However, precaution such as not using turbid semen, as found in some samples obtained by electroejaculation, help prevent false-positive results. Diagnosis of SRLV infection in males by this route may be useful to prevent infection dissemination (RAMÍREZ et al., 2009).

In the literature, more than 30 types of ELISA for diagnosis of SRLV are described (ANDRÉS et al., 2005; OIE, 2008). Some of them can be found commercially (Veterinary Diagnostic Technology, Inc. ${ }^{\circledR}$, Wheat Ridge, CO, USA; Biotracking, USA; Veterinary Medical Research \& Development, UK; IDvet Innovative Diagnostics, France). In Brazil, use of
ELISA is limited to scientific research as the test is still not commercially available. In the last 30 years, such limitation has prevented in practice the progress of CAE control programs in Brazilian commercial goat herds, which are still monitored by AGID. Thus, the herds have a low percentage of false-negative goats, which remain undetected by AGID but could be detected by ELISA (GOUVEIA, 2012).

\section{Western blot (WB) and dot blot (DB)}

In $\mathrm{WB}$, proteins (serum or plasma antibodies) are immobilized on a membrane and separated by electrophoresis. Subsequently, the antigen-antibody complex is visualized by applying an enzyme conjugate. This technique is time-consuming and laborious, but it is considered as a complementary technique in the diagnosis of SRLV to clarify divergent results involving diagnostic tests such as ELISA and AGID. In addition, it is used as the gold standard of comparison in the standardization of new tests to determine their relative sensitivity and specificity (SAMAN et al., 1999; OIE, 2008; PINHEIRO et al., 2011).

This technique allows detection by molecular weight of antibodies to various viral proteins including matrix protein (14-16 kDa), inner capsid protein $(28 \mathrm{kDa})$, transmembrane glycoprotein $(40$ $\mathrm{kDa})$, a $45-\mathrm{kDa}$ protein, possibly precursor protein gag gene $(50 \mathrm{kDa})$, a $67-\mathrm{kDa}$ glycoprotein, and surface glycoprotein gp70 $(70 \mathrm{kDa})$. The viral capsid protein $(28 \mathrm{kDa})$ is most evident in the test by its abundance in the virus, whereas the gp 135 protein is evident only in extremely positive sera (OLIVEIRA et al., 2008; PINHEIRO et al., 2011; RODRIGUES et al., 2014).

Western blot is capable of early detection of positive animals and has greater sensitivity and specificity when compared to other serological techniques such as AGID and ELISA (Table 1) (RODRIGUES et al., 2014). In experimentally infected goats, antibodies to the SRLV protein $\mathrm{p} 28$ were visualized by this technique four days pi. At two weeks pi it was also possible to 
detect antibodies to other viral proteins, gp125 and gp90 (DING; XIANG, 1997). Decreased occurrence of nonspecific reactions is another advantage of the $\mathrm{WB}$, and the presence of false-positive results in the diagnosis is thus reduced (ZANONI; KRIEG; PETERHANS, 1989).

The WB technique has a potential use in SRLV diagnosis because it is useful in later stages of control programs, resolves conflicting results between other diagnostic techniques, and contributes to eliminating positive animals from herds.

The DB technique is another option for SRLV diagnosis. It is a qualitative test, with high sensitivity and good specificity (Table 1). It uses the whole virus as antigen adsorbed onto nitrocellulose strips, and allows rapid antibody detection. This technique is low cost and practical to run. It can be used in a large number of animals and its use would be indicated on occasions such as participation of animals in agricultural and livestock events, thus avoiding SRLV infection from being disseminated (PINHEIRO et al., 2006a, b).

Although WB and DB can be useful as aid techniques in a CAE control program, they are not commercially available.

\section{Prophylaxis and strategies for the control and eradication of SRLV}

In order to prevent infection or control the infected herds, persistence of SRLV infection, absence of treatment or vaccines, and high cost of measures proposed for an adequate control of CAE should be considered. Thus, taking management measures and monitoring the herd with tests for SRLV diagnosis to avoid losses due to the disease would be ideal (CALLADO; CASTRO; TEIXEIRA, 2001; PETERHANS et al., 2004; REINA et al., 2009; GOUVEIA, 2012).

Trade in animals is considered an important risk factor for SRLV dissemination (PETERHANS et al., 2004; LIN et al., 2011) and control of animal movement is essential to prevent infection dissemination within herds. All animal handling such as purchase, exchange, or return from an event and exhibition should be preceded by requirement of a health certificate. Furthermore, it should be followed by a quarantine period during which retesting the animals on the property 60 days after serological examination (held at the time of purchase, exchange, or participation on agricultural fair) (ROWE et al., 1992b; GUIMARÃES et al., 2009; GOUVEIA, 2012; SARDI et al., 2012). In the purchase, loan, or exchange of animals, use of high-sensitivity tests such as ELISA and DB should be indicated to prevent acquisition of false-negative animals. Later, during quarantine, a more specific technique such as AGID should be used to confirm the diagnosis. However, unavailability of commercial reagents prevents this practice (GOUVEIA, 2012).

To prevent SRLV introduction into a virus-free property or region, trade in animals, embryos, and semen must be controlled because infection by these routes is possible. Semen samples should be tested using molecular techniques after each batch is collected; embryos must be washed and processed according to the guidelines of the International Embryo Transfer Society (IETS) (ANDRIOLI et al., 1999; REINA et al., 2009).

In properties where presence of $\mathrm{CAE}$ must be controlled, the necessary measures will vary according to the health status of the herd. Measures are based on blocking the routes of virus transmission from infected animals, taking into account the routes of infection and factors such as late seroconversion, viral latency, and herd management (ROWE; EAST, 1997; PINHEIRO et al., 2010; GOUVEIA, 2012).

In control programs, the time and frequency to conduct serological tests are fundamental. The time interval between tests depends on the speed intended to achieve the control program objectives. The higher the frequency, the greater the segregation between seropositive and seronegative animals and the earlier the objectives will be achieved (GOUVEIA, 2012). 
The choice of diagnostic techniques to periodically perform tests depends not only on their sensitivity or specificity but also on the availability of laboratories and commercial immunoreactants, in addition to the cost for their use.

High rates of false-negative sera are observed when AGID is used as the sole method for SRLV diagnosis. Thus, control of the disease is not fully effective in achieving eradication. Adopting a diagnostic approach in three stages (initial screening of whole herd by ELISA and confirmation of seropositive results by AGID) is recommended so that programs for control and eradication of SRLV become faster and more efficient. In the few cases in which divergence may occur, the sera should be submitted to WB. Thus, high-sensitivity of ELISA will be combined with highspecificity of AGID and power of WB for an accurate diagnosis of SRLV (GOUVEIA, 2012; RODRIGUES et al., 2014).

However, a three-stage diagnostic approach involves high costs. In practice, it is limited by unavailability of routine diagnosis in Brazil, due to lack of either commercialized immunoreagents or laboratories where routine diagnoses are available. Such lack has contributed to failure in later stages of control programs, when detection and elimination of falsenegative animals is preponderant (GOUVEIA, 2012).

In all stages of the control program, detecting the true-negative animals is essential. However, the diagnostic techniques should be chosen according to the cost-benefit ratio, commercial availability, and access to diagnostic laboratories (GOUVEIA, 2012). When only AGID diagnosis is available, given its high specificity (Table 1), monitoring by AGID in the early stages of SRLV control programs can be used alone (VAREA et al., 2001; PINHEIRO et al., 2006a; GOUVEIA, 2012). This strategy allows falsenegative goats to remain in the herd for a longer time, thus contributing to virus transmission. However, the control program should be monitored as soon as possible by introducing ELISA, and eventually WB.
By using the three-stage diagnostic approach (ELISA, AGID, and WB), closed herds will be considered negative to SRLV after four negative serological tests throughout the breeding stock with six-month intervals (GOUVEIA, 2012).

Seropositive animals should be euthanized. In case of high genetic value, seropositive animals should be segregated and visually identified with a permanent mark. In addition, management measures that both take into account transmission routes and preventing direct or indirect contact between lots of seropositive and seronegative goats should be associated. In practice, segregation within a herd is a difficult measure because there are other routes by which SRLV can be transmitted. Therefore, contact between animals and transmission via aerosol should be restricted. The control of SRLV can be made semiannually by high-sensitivity serological tests, such as ELISA, and confirmed by AGID, with segregation and progressive disposal of positive animals, and gradual reduction in the prevalence rate (REINA et al., 2009; KONISHI et al., 2011; GOUVEIA, 2012).

Prevention of perinatal infection is another measure to obtain negative goats from seropositive female goats. Segregation between offspring and mothers should take place soon after delivery to prevent babies from being contaminated via intake of colostrum from mothers infected with SRLV and contact with secretions during delivery (ADAMS et al., 1983; ROWE et al., 1992a, b; ROWE; EAST, 1997; LEITNER et al., 2010).

Young goats separated from their mothers at birth should be segregated in small groups in bays apart from the rest of the herd (at least $50 \mathrm{~m}$ ) to prevent transmission via aerosol or contact with older animals. Initially, they should be fed negative-goat colostrum heated in water bath $\left(1 \mathrm{~h} ; 56^{\circ} \mathrm{C}\right)$. Subsequently, they must be suckled with seronegative goat's pasteurized milk or substitutes such as cow's milk, or even other substitutes (ADAMS et al., 1983; ROWE et al., 1992a, b; ROWE; EAST, 1997; LEITNER et al., 2010; GOUVEIA, 2012). 
Antibody detection in goats separated from their mothers at birth should be performed bimonthly when they are 2-6 months old (GOUVEIA, 2012). Animals infected by the maternal-fetal route or contact with secretion during delivery may have delayed seroconversion ( 5 or more months) (EAST et al., 1993; STACHISSINI et al., 2007).

CAE control by providing heat-treated colostrum to young goats at birth is facilitated in properties with goat colostrum bank (PINHEIRO et al., 2004).

Iatrogenic transmission should be avoided by using individual needles and sterile equipment and using proper hygiene in the milking machine. Improper hygiene of this equipment may favor penetration of microorganisms such as SRLV in the mammary gland (EAST et al., 1993; LARA et al., 2003; NOGUEIRA; PINHEIRO; ALVES, 2009). In order to maintain a good health of udders and sanity of the herd, a milking line can be organized, in which negative females are milked before the seropositive ones and younger animals are milked before the older ones (NOGUEIRA et al., 2008; GOUVEIA, 2012). It is noteworthy that separation by age group, productive situation (initial pregnant, final pregnant, or lactating), and range of milk production by lactating animals are already used in the breeding routine. Therefore, subdivision of these (many) categories segregating seropositive and seronegative groups in the facilities and milking parlor is necessary when the CAE control program is established for the dairy herd. Subdivision in more categories increases the cost and complicates management due to increase in manpower and need for a greater number of division bays (GOUVEIA, 2012).

Adoption of a breeding season seeks to concentrate births in a period, thus facilitating the monitoring of pups and reducing mortality rates. Furthermore, it seeks to facilitate CAE control by immediately removing the neonate goat to minimize this contact with the female, especially if it is seropositive or comes from an infected herd (PINHEIRO et al., 2004; SANTOS; ALFARO; FIGUEIREDO, 2011).
The possibility of SRLV transmission by semen points to the need for health monitoring of breeding animals about 30 days before the breeding season with the use of high-sensitivity serological test (ELISA) in blood serum and semen samples to eliminate intermittent CAEV in semen (ANDRIOLI et al., 1999; ANDRIOLI; GOUVEIA; PINHEIRO, 2003; ANDRIOLI; SANTOS; ELOY, 2006; ALI AL AHMAD et al., 2008; CRUZ et al., 2009a; CRUZ, 2009; RAMÍREZ et al., 2009). In a study on the profile of virus elimination from semen and blood and serological curve with weekly monitoring for 12 months, intermittent detection of virus (by PCR of seminal fluid, sperm fraction, and blood leukocyte cream) and serum antibodies was observed. The authors suggest the association of at least two of these techniques for SRLV diagnosis in goat breeders (CRUZ, 2009).

The use of reproductive biotechnologies such as artificial insemination and embryo transfer contributes to the control of CAE and allows for a potential use of seropositive breeders of high genetic value. These breeders of high genetic value may eventually be used for semen collection and use of negative SRLV lots since elimination of virus in semen is intermittent (ANDRIOLI et al., 1999; ANDRIOLI; GOUVEIA; PINHEIRO, 2003; ANDRIOLI; SANTOS; ELOY, 2006; ALI AL AHMAD et al., 2008; CRUZ et al., 2009a; CRUZ, 2009; RAMÍREZ et al., 2009). Seropositive breeding animals of high genetic value may also be preserved temporarily (in the early stages of control) to cover seropositive females, if any, in the herd, thus avoiding contaminating seronegative goats in mating with seropositive females (GOUVEIA, 2012).

In mixed herds of sheep and goats, the success of the control program will be jeopardized unless both species are included, because some goat herds in contact with SRLV-positive sheep showed a higher rate of seroconversion (BRÜLISAUER et al., 2005; GJERSET et al., 2009; GHANEM et al., 2009).

The impact of SRLV infection decreases markedly when prevalence in herds is reduced. The goal of 
reaching the SRLV-free status in herds is to ensure security in movement of animals, adding value to the product and reducing risks of disease dissemination (REINA et al., 2009).

Possible application of a CAE control or eradication program should be analyzed separately, in each property, municipality, state, or country, and the benefits and costs of implementation should be considered aiming at the best economic profitability of goat production. In order to implement a control or eradication program, determining prevalence of the disease should be the first action (PINHEIRO et al., 2001; PETERHANS et al., 2004; GOUVEIA, 2012).

Based on laboratory tests, herds are classified as null (SRLV-free herd), very low (1-9\%), low (10-39\%), intermediate (40-69\%), or high (> 70\%), defining the measures to be adopted as follows. In areas with low prevalence of CAE (or a relatively small number of animals), the strategy of test and sacrifice of seropositive animals can be adopted (REINA et al., 2009; GOUVEIA, 2012).

Serology and sacrifice of seropositive animals was the strategy used in countries such as New Zealand and Australia, which eradicated CAE using a government subsidy (ROWE; EAST, 1997; PETERHANS et al., 2004). The advantages of eradicating the disease include preventing production losses, improving both animal welfare and production, decreasing the rate of disposal of sick animals, eliminating unnecessary veterinary costs, and adding value to the herd (movement of animals without disseminating the virus) (REINA et al., 2009).

Some breeders give up participating in CAE eradication programs due to lack of understanding of the routes of transmission of such infections, benefits of identifying and removing infected animals after test in the original herd, and potential risk of introducing new animals in the herd without applying specific tests (ROWE; EAST, 1997). This indicates that they lack knowledge of the benefits of disease eradication. Therefore, it is necessary to provide breeders with information about SRLV infection.

The efficiency of SRLV control and eradication programs depends on sensitivity and specificity of diagnostic tests, frequency of their use in the herd, and management and commitment of all actors involved, such as government, technicians, and breeders. Since all diagnostic techniques have limitations, a combination of techniques is indicated to identify the maximum number of animals infected with SRLV. In choosing the serological test for use in a control or eradication program, the viral heterogeneity should be considered in order to detect antibodies to antigens present in samples of the population. However, the availability of commercial immunoreagents and cost of serological tests are limiting factors for the success of CAE control and eradication programs. 


\section{References}

ABREU, S. R. O.; CASTRO, R. S.; NASCIMENTO, S. A.; SOUZA, M. G. Produção de antígeno nucleoprotéico do vírus da artrite-encefalite caprina e comparação com o do vírus Maedi-Visna para utilização em teste de imunodifusão em ágar gel. Pesquisa Veterinária Brasileira, v. 18, n. 2, p. 57-60, 1998. Available from: <http://www.scielo.br/scielo.php?pid=S0100736X1998000200003\&script=sci_arttext>. Viewed: 20 July 2014. doi: http://dx.doi.org/10.1590/S0100-736X1998000200003.

ADAMS, D. S.; CRAWFORD, T. B.; BANKS, K. L.; McGUIRE, T. C.; PERRYMAN, L. E. Immune responses of goats persistently infected with caprine arthritis-encephalitis virus. Infection and Immunity, v. 28, n. 2, p. 421-427, 1980. Available from: <http:// www.ncbi.nlm.nih.gov/pmc/articles/PMC550952/>. Viewed: 27 Aug. 2015.

ADAMS, D. S.; GORHAM, J. R. The gp135 of caprine arthritis encephalitis virus affords greater sensitivity than the p28 in immunodiffusion serology. Research in Veterinary Science, v. 40, n. 2, p. 157-160, 1986.

ADAMS, D. S.; KLEVJER-ANDERSON, P.; CARLSON, J. L; McGUIRE, T. C.; GORHAM, J. R. Transmission and control of caprine arthritis-encephalitis virus. American Journal of Veterinary Research, v. 44, n. 9, p. 1670-1675, 1983.

ALI AL AHMAD, M. Z.; FIENI, F.; PELLERIN, J. L.; GUIGUEN, F.; CHEREL, Y.; CHATAGNON, G.; BOUZAR, A. B.; CHEBLOUNE, Y. Detection of viral genomes of caprine arthritisencephalitis virus (CAEV) in semen and in genital tract tissues of male goat. Theriogenology, v. 69, n. 4, p. 473-80, 2008. Available from: <http://www.sciencedirect.com/science/article/pii/S00 93691X07006322>. Viewed: 2 June 2015. doi: http://dx.doi. org/10.1016/j.theriogenology.2007.10.017.

ALVES, F. S. F. Teste de imunodifusão em gel de agarose no diagnóstico da artrite e encefalite caprina utilizando antígenos do lentivírus caprino e ovino. Embrapa Caprinos, n. 51, p. 1-3, 1999. Available from: <https://www.embrapa.br/busca-depublicacoes/-/publicacao/515272/teste-de-imunodifusao-emgel-de-agarose-no-diagnostico-da-artrite-encefalite-caprinautilizando-antigenos-do-lentivirus-caprino-e-ovino $>$. Viewed: 27 July 2014.

ANDRÉS, D.; KLEIN, D.; WATT, N. J.; BERRIATUA, E.; TORSTEINSDOTTIR, S.; BLACKLAWS, B. A.; HARKISS, G. D. Diagnostic tests for small ruminant lentiviruses. Veterinary Microbiology, v. 107, n. 1-2, p. 49-62, 2005. Available from: $\quad<\mathrm{http}: / /$ www.sciencedirect.com/science/article/pii/ S0378113505000374>. Viewed: 2 June 2014. doi: http://dx.doi. org/10.1016/j.vetmic.2005.01.012.

ANDRIOLI, A.; GOUVEIA, A. M. G.; PINHEIRO, R. R. Seleção de sêmen de reprodutores portadores do vírus da artrite encefalite caprina através da técnica de reação em cadeia da polimerase. Embrapa Caprinos, n. 50, p. 1-23, 2003. Available from: <http:// www.infoteca.cnptia.embrapa.br/handle/doc/531309>. Viewed: 24 July 2014.

ANDRIOLI, A.; GOUVEIA, A. M. G.; PINHEIRO, R. R.; ROCHA, M. A.; MARTINS, A. S.; SANTOS, D. O. Detecção do DNA próviral do lentivírus caprino em sêmen de bodes naturalmente infectados. Revista Brasileira de Reprodução Animal, v. 23, n. 3, p. 420-421, 1999. Available from: <http://www.alice.cnptia. embrapa.br/bitstream/doc/515208/1/RACDeteccaodoDNA. pdf $>$. Viewed: 7 July 2014.

ANDRIOLI, A.; SANTOS, D. O.; ELOY, A. M. X. Manejo reprodutivo de matrizes e reprodutores caprinos em sistema de produção de leite. Embrapa Caprinos, n. 65, p. 1-33, 2006. Available from: <http://ainfo.cnptia.embrapa.br/digital/ bitstream/CNPC/20259/1/doc65.pdf>. Viewed: 5 July 2014.

BARQUERO, N.; ARJONA, A.; DOMENECH, A.; TOURAL, C.; HERAS, A.; FERNÁNDEZ-GARAYZABAL, J. F.; RUIZ-SANTA
QUITERIA, J. A.; GOMEZ-LUCIA, E. Diagnostic performance of PCR and ELISA on blood and milk samples and serological survey for small ruminant lentiviruses in central Spain. Veterinary Record, v. 168, n. 20, 2011. Available from: <http:// veterinaryrecord.bmj.com/content/168/1/20.long $>$. Viewed: 2 July 2014. doi: http://dx.doi.org/10.1136/vr.c4951.

BERTONI, G. Caprine arthritis encephalitis complex. In: TEMPESTA, M. (Ed.). Recent advances in goat diseases. Ithaca: International Veterinary Information Service, 2007. Available from: <http://boris.unibe.ch/25340/1/cae.pdf>. Viewed: 10 Apr. 2012 .

BIRGEL JUNIOR, E. H.; CESTARI, V.; SAMPAIO, R. M.; LARA, M. C. C. S. H.; BIRGEL, D. B.; RAIMONDO, R. F. S.; BRANDESPIN, F. B.; BIRGEL, E. H. Influência da infecção pelo vírus da artrite encefalite caprina nas características físicoquímicas e celulares do leite de caprinos. Arquivos do Instituto Biológico, v. 74, n. 3, p. 199-206, 2007. Available from: <http:// www.biologico.sp.gov.br/docs/arq/v74_3/birgel.pdf $>$. Viewed: 5 June 2014

BRANDÃO, C. F. L.; CAMPOS, G. S.; SILVA, A. C. R.; TORRES, J. A.; TIGRE, D. M.; SARDI, S. I. Monoclonal antibodies against Caprine arthritis-encephalitis virus epitopes in the p28 and p55 gag viral proteins. Journal of Virological Methods, v. 187, p. 352-356, 2013. Available from: <http://www.sciencedirect.com/science/ article/pii/S0166093412003849>. Viewed: 6 Feb. 2015. doi: http:// dx.doi.org/10.1016/j.jviromet.2012.10.020.

BRÜLISAUER, F; VOGT, H. R.; PERLER, L.; RÜFENACHT, J. Risk factors for the infection of Swiss goat herds with small ruminant lentivirus: a case control study. The Veterinary Record, v. 157, n. 8, p. 229-233, 2005. Available from: <http:// veterinaryrecord.bmj.com/content/157/8/229.long $>$. Viewed: 3 July 2014. doi: http://dx.doi.org/10.1136/vr.157.8.229.

CALlADO, A. K. C.; CASTRO, R. S.; TEIXEIRA, M. F. S. Lentivírus de pequenos ruminantes (CAEV e Maedi-visna): revisão e perspectivas. Pesquisa Veterinária Brasileira, v. 21, n. 3, p. 87-97, 2001. Available from: <http://www.scielo. br/scielo.php?pid=S0100-736X2001000300001\&script $=$ sci abstract\&tlng=pt $>$. Viewed: 5 June 2013. doi: http://dx.doi. org/10.1590/S0100-736X2001000300001.

CARDINAUX, L.; ZAHNO, M. L.; DEUBELBEISS, M.; ZANONI, R.; VOGT, H. R.; BERTONI, G. Virological and phylogenetic characterization of attenuated small ruminant lentivirus isolates eluding efficient serological detection. Veterinary Microbiology, v. 162 , n. $2-4$, p. $572-581,2013$. Available from: <http://www. sciencedirect.com/science/article/pii/S0378113512006086>. Viewed: 6 Feb. 2015. doi: http://dx.doi.org/10.1016/j. vetmic.2012.11.017.

CARNEIRO, F. F. D.; BRITO, R. L. L.; SANTOS, V. W. S.; GOMES, T. C. L.; ANDRIOLI, A.; PINHEIRO R. R. Perdas econômicas decorrentes da artrite-encefalite caprina na produção de gordura e sólidos totais de leite. Revista Científica de Produção Animal, v. 13, n. 1, p. 130-134, 2011. Available from: <http:// ainfo.cnptia.embrapa.br/digital/bitstream/item/112085/1/APPerdas-economicas.pdf $>$. Viewed: 6 Feb. 2015. doi: http://dx.doi. org/10.15528/2176-4158/rcpa.v13n1p130-134.

CHEEVERS, W. P.; McGUIRE, T. C. The lentiviruses: maedi/ visna, caprine arthritis-encephalitis, and equine infectious anemia. Advances in Virus Research, v. 34, p. 189-215, 1988. Available from: <http://www.sciencedirect.com/science/article/ pii/S0065352708605187>. Viewed: 7 June 2014. doi: http://dx.doi. org/10.1016/S0065-3527(08)60518-7.

CORTEZ-MOREIRA, M.; OELEMANN, W. M. R.; LILENBAUM, W. Comparison of serological methods for the diagnostic of Caprine arthritis-encephalitis (CAE) in Rio de Janeiro, Brazil. 
Brazilian Journal of Microbiology, n. 36, n. 1, p. 48-50, 2005. Available from: <http://www.scielo.br/scielo.php?script=sci arttext\&pid=S1517-83822005000100010\&lng=en\&nrm=iso\&tln $\mathrm{g}=\mathrm{en}>$. Viewed: 3 July 2014. doi: http://dx.doi.org/10.1590/S151783822005000100010 .

CRUZ, J. C. M. Monitoramento sorológico e da presença do DNA pró-viral do lentivírus caprino (CAEV) no sangue e sêmen de reprodutores infectados. 2009. 35 f. Tese (Doutorado em Ciência Animal) - Escola de Veterinária, Universidade Federal de Minas Gerais, Belo Horizonte, 2009.

CRUZ, J. C. M.; GOUVEIA, A. M. G.; SOUZA, K. C.; BRAZ, G. F.; TEIXEIRA, B. M.; HEINEMANN, M. B.; LEITE, R. C.; REIS, J. K. P.; PINHEIRO, R. R.; ANDRIOLI, A. Caprine arthritis-encephalitis virus (CAEV) detection in semen of endangered goat breeds by nested polymerase chain reaction. Small Ruminant Research, v. 85, n. 2-3, p. 149-152, 2009a. Available from: <http://www.sciencedirect.com/science/article/ pii/S0921448809001369>. Viewed: 3 Apr. 2013. doi: http://dx.doi. org/10.1016/j.smallrumres.2009.07.010.

CRUZ,R.B.;PUTINI,V.B.;SANTANA,G.S.;JORGE,J.S.;COELHO I.; SILVA, D. L.; ZACHARIAS, F.; TIGRE, D.; CERQUEIRA, R. B. Estudo comparativo da sensibilidade e da especificidade de ELISA indireto com o teste de imunodifusão em gel de agarose no diagnóstico sorológico da artrite encefalite caprina (CAEV). Revista Acadêmica: Ciências Agrárias e Ambiente, Curitiba, v. 7 , n. 3, p. 355-364, 2009b. Available from: <http://www2.pucpr.br/ reol/index.php/ACADEMICA?dd1 $=3470 \& d d 99=v i e w>$. Viewed: 2 July 2013.

CRUZ, J. C. M.; SINGH, D. K.; LAMARA, A.; CHEBLOUNE, Y. Small Ruminant Lentiviruses (SRLVs) break the species barrier to acquire new host range. Viruses, v. 5, n. 7, p. 1867-1884, 2013. Available from: <http://www.mdpi.com/1999-4915/5/7/1867>. Viewed: 7 July 2014. doi: http://dx.doi.org/10.3390/v5071867.

DING, E. Y.; XIANG, W. H. Immune response in goats to caprine arthritis-encephalitis virus. Viral Immunology, v. 10, n. 2, p. 111$115,1997$.

EAST, N. E.; ROWE, J. D.; DAHLBERG, J. E.; THEILEN, G. H.; PEDERSEN, N. C. Modes of transmission of caprine arthritisencephalitis virus infection. Small Ruminant Research, v. 10, n. 3, p. 251-262, 1993. doi:10.1016/0921-4488(93)90130-A.

FLURI, A.; NENCI, C.; ZAHNO, M. L.; VOGT, H. R.; CHARAN, S.; BUSATO, A.; PANCINO, G.; PETERHANS, E.; OBEXERRUFF, G.; BERTONI, G. The MHC-haplotype influences primary, but not memory, immune responses to an immunodominant peptide containing $\mathrm{T}$ - and B-cell epitopes of the caprine arthritis encephalitis virus Gag protein. Vaccine, v. 24, n. 5, p. 597-606, 2006. Available from: <http://linkinghub.elsevier.com/retrieve/ pii/S0264-410X(05)00848-0>. Viewed: 6 Feb. 2015. doi: http:// dx.doi.org/10.1016/j.vaccine.2005.08.043.

GHANEM, Y. M.; EL-KHODERY, S. A.; SAAD, A. A.; ELRAGABY, S. A.; ABDELKADER, A. H.; HEYBE, A. Prevalence and risk factors of caprine arthritis encephalitis virus infection (CAEV) in Northern Somalia. Small Ruminant Research, v. 85, n. 2-3, p. 142-148, 2009. Available from: <http://www.sciencedirect.com/ science/article/pii/S0921448809001631>. Viewed: 23 Aug. 2014. doi: http://dx.doi.org/10.1016/j.smallrumres.2009.09.005.

GJERSET, B.; RIMSTAD, E.; TEIGE, J.; SOETAERT, K.; JONASSEN, C. M. Impact of natural sheep-goat transmission on detection and control of small ruminant lentivirus group $\mathrm{C}$ infections. Veterinary Microbiology, v. 135, n. 3-4, p. 231-238, 2009. Available from: <http://www.sciencedirect.com/science/ article/pii/S0378113508004446>. Viewed: 20 Feb. 2013. doi: http://dx.doi.org/10.1016/j.vetmic.2008.09.069.

GOUVEIA, A. M. G. Lentiviroses de pequenos ruminantes. Cadernos Técnicos de Veterinária e Zootecnia, n. 64, p. 46-59, 2012. Available from: <http://www.crmvmg.org.br/ cadernotecnico/64.pdf $>$. Viewed: 20 July 2013.
GUIMARÃES, A. S.; SEYFFERT, N.; BASTOS, B. L.; PORTELA, R. W. D.; MEYER, R.; CARMO, F. B.; CRUZ, J. C. M.; McCULLOCH, J. A.; LAGE, A. P.; HEINEMANN, M. B.; MIYOSHI, A.; AZEVEDO, V.; GOUVEIA, A. M. G. Caseous lymphadenitis in sheep flocks of the state of Minas Gerais, Brazil: prevalence and management surveys. Small Ruminant Research, v. 87, n. 1-3, p. 86-91, 2009. Available from: <http://www.sciencedirect.com/ science/article/pii/S0921448809001850>. Viewed: 21 Oct. 2015. doi: http://dx.doi.org/10.1016/j.smallrumres.2009.09.027.

HANSON, J.; HYDBRING, E.; OLSSON, K. A long term study of goats naturally infected with caprine arthritis-encephalitis virus. Acta Veterinaria Scandinavica, v. 37, n. 1, p. 31-39, 1996.

HERRMANN-HOESING, L. M. Diagnostic assays used to control small ruminant lentiviruses. Journal of Veterinary Diagnostic Investigation, v. 22, n. 6, p. 843-855, 2010. Available from: <http://vdi.sagepub.com/cgi/pmidlookup?view=long\&pm $\mathrm{id}=21088167>$. Viewed: 3 July 2014 . doi: http://dx.doi.org/10.11 $77 / 104063871002200602$

INTERNATIONAL COMMITTEE ON TAXONOMY OF VIRUSES - ICTV. 2013. Available from: <http://ictvonline.org/ virusTaxonomy.asp $>$. Viewed: 20 Feb. 2013.

KAJIKAWA, O.; LAIRMORE, M. D.; DEMARTINI, J. C. Analysis of antibody responses to phenotypically distinct lentiviruses. Journal of Clinical Microbiology, v. 28, n. 4, p. 764-770, 1990. Available from: <http://www.ncbi.nlm.nih.gov/pmc/articles/ PMC267790/pdf/jcm00052-0135.pdf>. Viewed: 7 July 2014.

KLEIN, J. R.; MARTIN, J.; GRIFFING, S.; NATHANSON, N.; GORHAM, J.; SHEN, D. T.; PETURSSON, G.; GEORGSSON, G.; PALSSON, P. A.; LUTLEY, R. Precipitating antibodies in experimental visna and natural progressive pneumonia of sheep. Research in Veterinary Science, v. 38, n. 2, p. 129-133, 1985.

KNOWLES JUNIOR, D. P.; EVERMANN, J. F.; SHROPSHIRE, C.; VANDERSCHALIE, J.; BRADWAY, D.; GEZON, H. M.; CHEEVERS, W. P. Evaluation of agar gel immunodiffusion serology using caprine and ovine lentiviral antigens for detection of antibody to caprine arthritis-encephalitis virus. Journal of Clinical Microbiology, v. 32, n. 1, p. 243-245, 1994. Available from: <http://jcm.asm.org/content/32/1/243>. Viewed: 8 July 2013.

KONISHI, M.; NAGURA, Y.; TAKEI, N.; FUJITA, M.; HAYASHI, K. ; TSUKIOKA, M.; YAMAMOTO, T.; KAMEYAMA, K.; SENTSUI, H.; MURAKAMI, K. Combined eradication strategy for CAE in a dairy goat farm in Japan. Small Ruminant Research, v. 99, n. 1, p. 65-71, 2011. Available from: <http://www.sciencedirect. com/science/article/pii/S092144881100126X>. Viewed: 2 July 2014. doi: http://dx.doi.org/10.1016/j.smallrumres.2011.03.051.

LARA, M. C. C. S. H.; BIRGEL JUNIOR, E. H.; FERNANDES, M. A.; BIRGEL, E. H. Infecção experimental do vírus da artriteencefalite dos caprinos em cabritos. Arquivos do Instituto Biológico, v. 70, n. 1, p. 51-54, 2003. Available from: <http:// www.biologico.sp.gov.br/docs/arq/V70_1/lara.pdf $>$. Viewed: 21 July 2014

LARA, M. C. C. S. H.; BIRGEL JUNIOR, E. H.; REISCHAK, D.; MOOJEN, V.; GREGORY, L.; OLIVEIRA, J. C. F.; BIRGEL, E. H. Identificação imuno-sorológica de anticorpos anti-vírus da Artrite-encefalite dos caprinos: comparação das técnicas de imunodifusão em gel de ágar, ensaio imunoenzimático e imunofluorescência indireta. Arquivos do Instituto Biológico, v. 69, n. 4 , p. 1-5, 2002. Available from: <http://www.biologico. sp.gov.br/docs/arq/V69_4/lara.pdf>. Viewed: 2 July 2014.

LEITNER, G.; KRIFUCKS, O.; WEISBLIT, L.; LAVI, Y.; BERNSTEIN, S.; MERIN, U. The effect of caprine arthritis encephalitis virus infection on production in goats. The Veterinary Journal, v. 183, n. 3, p. 328-331, 2010. Available from: $\quad<\mathrm{http}: / /$ linkinghub.elsevier.com/retrieve/pii/S10900233(08)00420-6>. Viewed: 12 July 2014. doi: http://dx.doi. org/10.1016/j.tvjl.2008.12.001. 
LIN, T. N.; NGARMKUM, S.; ORAVEERAKUL, K.; VIRAKUL, P.; TECHAKUMPHU, M. Seroprevalence and risk factors associated with caprine arthritis-encephalitis virus infection in goats in the Western part of Thailand. The Thai Journal of Veterinary Medicine, v. 41, n. 3, p. 353-360, 2011. Available from: <http:// www.tci-thaijo.org/index.php/tjvm/article/viewFile/9594/8663>. Viewed: 2 Apr. 2014.

MARTÍNEZ-NAVALÓN, B.; PERIS, C.; GÓMEZ, E. A.; PERIS, B.; ROCHE, M. L.; CABALLERO, C.; GOYENA, E.; BERRIATUA, E. Quantitative estimation of the impact of caprine arthritis encephalitis virus infection on milk production by dairy goats. The Veterinary Journal, v. 197, n. 2, p. 311-317, 2013. Available from: <http://www.sciencedirect.com/science/article/pii/ S1090023312005473>. Viewed: 10 Oct. 2013. doi: http://dx.doi. org/10.1016/j.tvjl.2012.12.020

MODOLO, J. R.; STACHISSINI, A. V. M.; PADOVANI, C. R.; ARAUJO JUNIOR, J. P.; CASTRO, R. S.; RAVAZZOLO, A. P.; LEITE, B. L. S. PCR associated with agar gel immunodiffusion assay improve caprine arthritis-encephalitis (CAEV) control. Small Ruminant Research, v. 81, n. 1, p. 18-20, 2009. Available from: $\quad<$ http://www.sciencedirect.com/science/article/pii/ S0921448808002150>. Viewed: 8 July 2014. http://dx.doi. org/10.1016/j.smallrumres.2008.10.005.

NOGUEIRA, D. M.; CHAPAVAL, L.; NEVES, A. L. A.; COSTA, M. M. Passos para obtenção de leite de cabra com qualidade. Petrolina: Embrapa Semi-Árido, 2008. 6 p. Available from: <http://www.infoteca.cnptia.embrapa.br/infoteca/bitstream/ doc/596035/1/COT135.pdf>. Viewed: 27 Aug. 2015.

NOGUEIRA, D. M.; PINHEIRO, R. R.; ALVES, F. S. Artrite encefalite caprina viral: um alerta aos produtores. Sobral: Embrapa Caprinos, 2009. Available from: <http://ainfo.cnptia. embrapa.br/digital/bitstream/item/17592/1/ComunicadoTecnico_2009.pdf>. Viewed: 27 Aug. 2015.

OIE. Manual of diagnostic tests and vaccines for terrestrial animals. 6. ed. Paris: OIE, 2008

OLIVEIRA, M. M. M.; MELO, M. A.; ANDRADE, P. P.; GOMES, S. M.; CAMPOS, A. C.; NASCIMENTO, S. A.; CASTRO, R. S. Western blot para o diagnóstico das infecções pelos lentivírus de pequenos ruminantes em caprinos: um método simples para a produção de antígeno. Arquivos do Instituto Biológico, v. 75, n. 3, p. 263-270, 2008. Available from: <http://www.biologico.sp.gov. br/docs/arq/v75_3/oliveira2.pdf >. Viewed: 16 July 2014.

PETERHANS, E.; GREENLAND, T.; BADIOLA, J.; HARKISS, G.; BERTONI, G.; AMORENA, B.; ELIASZEWICZ, M.; JUSTE, R. A.; KRAßNIG, R.; LAFONT, J. P.; LENIHAN, P.; PÉTURSSON, G.; PRITCHARD, G.; THORLEY, J.; VITU, C.; MORNEX, J. F.; PÉPIN, M. Routes of transmission and consequences of small ruminant lentiviruses (SRLVs) infection and eradication schemes. Veterinary Research, v. 35, n. 3, p. 257-274, 2004. Available from: <http://www.vetres.org/articles/vetres/abs/2004/03/ V4006/V4006.html>. Viewed: 20 July 2014. doi: http://dx.doi. org/10.1051/vetres:2004014.

PETROPOULOS, C. Retroviral taxonomy, protein structures, sequences and genetic maps. In: COFFIN, J. M.; HUGHES, S. H.; VARMUS, H. E. (Ed.). Retroviruses. Cold Spring Harbor: Cold Spring Harbor Laboratory, 1997. Available from: <http://www. ncbi.nlm.nih.gov/books/NBK19417/>. Viewed: 7 Feb. 2015.

PINHEIRO, R. R.; ANDRIOLI, A.; GOUVEIA, A. M. G.; ARAGÃO, M.A.C;MARTINEZ, P.M. Avaliação de antígenos para odiagnóstico de lentivírus em rebanho caprino sob programa de controle. Arquivos do Instituto Biológico, v. 77, n. 1, p. 133-137, 2010. Available from: <http://www.alice.cnptia.embrapa.br/bitstream/ doc/871563/1/NTAvaliacaodeantigenosparaodiagnosticode.pdf $>$. Viewed: 4 June 2014.

PINHEIRO, R. R.; GOUVEIA, A. M. G.; TORRES, A. M. C.; ANDRIOLI, A.; ALVES, F. S. F. Custo dos antígenos no diagnóstico de lentivírus de pequenos ruminantes. Revista
Brasileira de Medicina Veterinária, v. 28, n. 3, p. 110-113, 2006a. Available from: <http://ainfo.cnptia.embrapa.br/digital/ bitstream/item/53348/1/API-Custo-dos-antigenos.pdf >. Viewed: 18 Jan. 2013

PINHEIRO, R. R; BRITO, R. L. L; RODRIGUES, A. S.; DIAS, R. P.; ANDRIOLI, A.; GOUVEIA, A. M. G. Protocolo de immunoblotting para diagnóstico da artrite-encefalite caprina. Sobral: Embrapa Caprinos, 2011. 4 p. Available from: <http://www. infoteca.cnptia.embrapa.br/infoteca/bitstream/doc/903405/1/ UMTCOT122.pdf>. Viewed: 27 Aug. 2015.

PINHEIRO, R. R.; GOUVEIA, A. M. G.; ALVES, F. S. F. Prevalência da infecção pelo vírus da artrite encefalite caprina no estado do Ceará, Brasil. Ciência Rural, v. 31, n. 3, p. 449-454, 2001. Available from: <http://www.scielo.br/scielo.php?pid=S010384782001000300014\&script=sci_arttext $>$. Viewed: 10 July 2014. doi: http://dx.doi.org/10.1590/S0103-84782001000300014.

PINHEIRO, R. R.; GOUVEIA, A. M. G.; ALVES, F. S. F.; ANDRIOLI, A. Perfil de propriedades no estado do Ceará relacionado à presença do lentivírus caprino. Ciência Animal, v. 14, n. 1, p. 29-37, 2004. Available from: <http://ainfo.cnptia. embrapa.br/digital/bitstream/item/35693/1/API-Perfil-depropriedades.pdf $>$. Viewed: 10 July 2014.

PINHEIRO, R. R.; OLORTEGUI, C. D. C.; GOUVEIA, A. M. G.; ARAUJO, S. C.; ANDRIOLI, A. Desenvolvimento de dot-blot para detecção de anticorpos para o vírus da artrite-encefalite caprina em caprinos. Revista Portuguesa de Ciências Veterinárias, v. 101, p. 51-56, 2006b. Available from: <http://www.alice.cnptia. embrapa.br/handle/doc/909420>. Viewed: 10 Nov. 2013.

PISONI, G.; BERTONI, G.; PURICELLI, M.; MACCALLI, M.; MORONI, P. Demonstration of coinfection with and recombination by caprine arthritis-encephalitis virus and MaediVisna virus in naturally infected goats. Journal of Virology, v. 81, n. 10 , p. $4948-4955,2007$. Available from: <http://jvi.asm. org/content/81/10/4948.long>. Viewed: 18 June 2014. doi: http:// dx.doi.org/10.1128/JVI.00126-07.

PISONI, G.; QUASSO, A.; MORONI, P. Phylogenetic analysis of small ruminant lentivirus subtype B1 in mixed flocks: evidence for natural transmission from goats to sheep. Virology, v. 339, n. 2, p. 147-152. 2005. Available from: <http://www.sciencedirect. com/science/article/pii/S0042682205003417>. Viewed: 18 June 2014. doi: http://dx.doi.org/10.1016/j.virol.2005.06.013.

PLAZA, M.; SÁNCHEZ, A.; CORRALES, J. C.; FE, C.; CONTRERAS, A. Caprine arthritis encephalitis virus diagnosed by ELISA in lactating goats using milk samples. Small Ruminant Research, v. 81, n. 2-3, p. 189-192, 2009. Available from: <http://www.sciencedirect.com/science/article/pii/ S0921448808002514>. Viewed: 12 July 2014. doi: http://dx.doi. org/10.1016/j.smallrumres.2008.12.006.

RACHID, A.; CROISÉ, B.; RUSSO, P.; VIGNONI, M.; LACERENZA, D.; ROSATI, S.; KUZMAK, J.; VALAS, S. Diverse host-virus interactions following caprine arthritis-encephalitis virus infection in sheep and goats. Journal of General Virology, v. 94, p. 634-642, 2013. Available from: <http://vir.sgmjournals. org/cgi/pmidlookup?view=long\&pmid $=23197577>$. Viewed: 7 Feb. 2015. doi: http://dx.doi.org/10.1099/vir.0.044768-0.

RAMÍREZ, H.; ROMAN, B. S.; GLARIA, I.; REINA, R.; HERNÁNDEZ, M. M.; ANDRÉS, X.; CRESPO, H.; HICHOU, B.; CIANCA, S.; GONI, C.; GRANDAS, A.; GARCIAA-PASTOR, L.; VIJIL, L. E.; QUINTÍN, F.; GRILLÓ, M. J.; ANDRÉS, D.; AMORENA, B. Antibody-based diagnosis of small ruminant lentivirus infection in seminal fluid. Theriogenology, v. 72, n. 8, p. 1085-1096, 2009. Available from: <http://linkinghub.elsevier. com/retrieve/pii/S0093-691X(09)00317-3>. Viewed: 3 July 2014. doi: http://dx.doi.org/10.1016/j.theriogenology.2009.06.028.

RAVAZZOLO, A. P.; COSTA, U. Retroviridae. In: RAVAZZOLO, A. P.; COSTA, U.; FLORES, E. F. Virologia veterinária. Santa Maria: UFSM, 2007. p. 809-830. 
REINA, R.; BERRIATUA, E.; LUIÁN, L.; JUSTE, R.; SÁNCHEZ, A.; ANDRÉS, D.; AMORENA, B. Prevention strategies against small ruminant lentiviruses: an update. The Veterinary Journal, v. 182 n. 1, p. 31-37, 2009. Available from: <http://www.sciencedirect. com/science/article/pii/S1090023308001676>. Viewed: 12 June 2014. doi: http://dx.doi.org/10.1016/j.tvjl.2008.05.008.

RIMSTAD, E.; EAST, N. E.; TORTEN, M.; HIGGINS, J.; DEROCK, E.; PEDERSEN, N. C. Delayed seroconversion following naturally acquired caprine arthritis-encephalitis virus infection in goats. American Journal of Veterinary Research, v. 54, n. 11, p. 18581862,1993

RODRIGUES, A. S.; BRITO, R. L. L.; PINHEIRO, R. R.; DIAS, R. P.; ALVES, S. M.; SOUZA, T. S.; SOUZA, K. C.; AZEVEDO, D. A. A.; ANDRIOLI, A.; MAGALHÃES, D. C. T.; TEIXEIRA, M. F. S. Padronização do Elisa indireto e Western Blot para diagnóstico da artrite-encefalite caprina. Arquivo Brasileiro de Medicina Veterinária e Zootecnia, v. 66, n. 2, p. 417-424, 2014. Available from: <http://www.scielo.br/scielo.php?pid=S010209352014000200014\&script=sci_arttext $>$. Viewed: 7 Feb. 2015. doi: http://dx.doi.org/10.1590/1678-41626303.

ROWE, J. D.; EAST, N. E.; THURMOND, M. C.; FRANTI, C. E Risk factors associated with caprine arthritis-encephalitis virus infection in goats on California dairies. American Journal of Veterinary Research, v. 52, n. 3, p. 510-514, 1991.

ROWE, J. D.; EAST, N. E. Risk factors for transmission and methods for control of caprine arthritis encephalitis virus infection. Veterinary Clinics of North America: Food Animal Practice, v. 13, n. 1, p. 35-53, 1997.

ROWE, J. D.; EAST, N. E.; THURMOND, M. C.; FRANTI, C. E.; PEDERSEN, N. C. Cohort study of natural transmission and two methods for control of caprine arthritis-encephalitis virus infection in goats on a California dairy. American Journal of Veterinary Research, v. 53, n. 12, p. 2386-2395, 1992a.

ROWE, J. D.; EAST, N. E.; FRANTI, C. E.; THURMOND, M. C.; PEDERSEN, N. C.; THEILEN, G. H. Risk factors associated with the incidence of seroconversion to caprine arthritis encephalitis virus infection in goats on a California dairy. American Journal of Veterinary Research, v. 53, n. 12, p. 2396-2403, 1992b.

SAMAN, E.; EYNDE, G. V.; LUJAN, L.; EXTRAMIANA, B.; HARKISS, G.; TOLARI, F.; GONZALEZ, L.; AMORENA, B.; WATT, N.; BADIOLA, J. A new sensitive serological assay for detection of Lentivirus infections in small ruminants. Clinical and Diagnostic Laboratory Immunology, v. 6, n. 5, p. 734740, 1999. Available from: <http://www.ncbi.nlm.nih.gov/pmc/ articles/PMC95764/pdf/cd000734.pdf>. Viewed: 5 July 2014.

SANTOS, T. C. P.; ALFARO, C. E. P.; FIGUEIREDO, S. M Aspectos sanitários e de manejo em criações de caprinos e ovinos na microrregião de Patos, região semi-árida da Paraíba. Ciência Animal Brasileira, v. 12, n. 2, p. 206-212, 2011. Available from: <http://www.revistas.ufg.br/index.php/vet/article/ viewFile/4420/9214>. Viewed: 6 July 2014. doi: http://dx.doi. org/10.5216/cab.v12i2.4420.

SANTRY, L. A.; JONGA, J.; GOLDA, A. C.; WALSHA, S. R.; MENZIES, P. I.; WOOTTON, S. K. Genetic characterization of small ruminant lentiviruses circulating in naturally infected sheep and goats in Ontario, Canada. Virus Research, v. 175, n. 1, p. 3044, 2013. Available from: <http://www.sciencedirect.com/science/ article/pii/S0168170213001135>. Viewed: 6 Feb. 2015. doi: http:// dx.doi.org/10.1016/j.virusres.2013.03.019.

SARDI, S. I.; SENA, G. S. R.; CAMPOS, G. S.; SANTOS, G. R.; MAIA NETO, A. L.; AVILA, L. N. Ocorrência de lentivírus de pequenos ruminantes no semiárido baiano e perfil da caprino/ ovinocultura na região. Ciência Animal Brasileira, v. 13, n. 4, p. 494-503, 2012. Available from: <http://www.revistas.ufg.br/index. php/vet/article/view/17429>. Viewed: 2 July 2014. doi: http:// dx.doi.org/10.5216/cab.v13i4.17429.

SCHOBORG, R. V. Analysis of caprine arthritis encephalitis virus (CAEV) temporal gene expression in infected cells. Virus Research, v. 90, n. 1-2, p. 37-46, 2002. Available from: <http://www. sciencedirect.com/science/article/pii/S0168170202001430>. Viewed: 18 June 2014. doi: http://dx.doi.org/10.1016/S01681702(02)00143-0.

SHAH, C.; BÖNI, J.; HUDER, J. B.; VOGT, H. R.; MÜHLHERR, J.; ZANONI, R.; MISEREZ, R.; LUTZ, H.; SCHÜPBACH, J. Phylogenetic analysis and reclassification of caprine and ovine lentiviruses based on 104 new isolates: evidence for regular sheep-to-goat transmission and worldwide propagation through livestock trade. Virology, v. 319, n. 1, p. 12-26, 2004. Available from: <http://www.sciencedirect.com/science/article/pii/ S0042682203007645>. Viewed: 8 Feb. 2015. doi: http://dx.doi. org/10.1016/j.virol.2003.09.047.

SIMARD, C.; KIBENGE, M. T.; SINGH, P.; DIXON, P. Simple and rapid method for production of whole-virus antigen for serodiagnosis of caprine arthritis-encephalitis virus by enzymelinked immunosorbent assay. Clinical and Vaccine Immunology, v. 8, n. 2, p. 352-356, 2001. Available from: <http://cvi.asm.org/ cgi/pmidlookup?view=long\&pmid=11238221 $>$. Viewed: 12 July 2014. doi: http://dx.doi.org/10.1128/CDLI.8.2.352-356.2001.

STACHISSINI, A. V. M.; MODOLO, J. R.; CASTRO, R. S.; LEITE, B. L. S.; ARAUUJO JÚNIOR, J. P.; PADOVANI, C. R. Controle da artrite-encefalite caprina, em um capril comercial endemicamente contaminado. Brazilian Journal of Veterinary Research and Animal Science, v. 44, n. 1, p. 40-43, 2007. Available from: <http:// www.revistas.usp.br/bjvras/article/view/26659>. Viewed: 13 July 2014. doi: http://dx.doi.org/10.1590/S1413-95962007000100007.

TIGRE, D. M.; CAMPOS, G. S.; SARDI, S. I. Isolamento e identificação do vírus da artrite encefalite caprina, a partir do co-cultivo de células mononucleares do sangue com células de membrana sinovial de cabra. Revista de Ciências Médicas e Biológicas, v. 5, n. 2, p. 124-131, 2006. Available from: <http://www.portalseer.ufba.br/index.php/cmbio/article/ view/4119/3005>. Viewed: 14 July 2014.

TORRES, J. A.; CAMPOS, G. S.; FREITAS, M. M.; BRANDÃO, C. F. L.; SARDI, S. I. Produção de antígeno viral para o sorodiagnóstico da artrite-encefalite caprina utilizando um teste imunoenzimático (ELISA). Revista de Ciências Médicas e Biológicas, v. 8, n. 2, p. 107-114, 2009. Available from: <https:// repositorio.ufba.br/ri/bitstream/ri/1698/1/4059-9971-1-PB. pdf $>$. Viewed: 2 July 2014.

VAREA, R.; MONLEÓN, E.; PACHECO, C.; LUJÁN, L.; BOLEA, R.; VARGAS, M. A.; EYNDE, G. V.; SAMAN, E.; DICKSON, L.; HARKISS, G.; AMORENA, B.; BADIOLA, J. J. Early detection of maedi-visna (ovine progressive pneumonia) virus seroconversion in field sheep samples. Journal of Veterinary Diagnostic Investigation, v. 13, n. 4, p. 301-307, 2001. Available from: <http://vdi.sagepub.com/cgi/pmidlookup?view=long\& pmid=11478601 $>$. Viewed: 12 Aug. 2014. doi: http://dx.doi. org/10.1177/104063870101300404.

ZANONI, R.; KRIEG, A.; PETERHANS, E. Detection of antibodies to caprine arthritis-encephalitis virus by protein $G$ enzyme-linked immunosorbent assay and immunoblotting. Journal of Clinical Microbiology, v. 27, n. 3, p. 580-582, 1989. Available from: $<\mathrm{http}: / / \mathrm{jcm}$.asm.org/cgi/pmidlookup?view=long \&pmid=2541170 > . Viewed: 9 July 2014. 